\title{
EFFECTIVENESS OF LEMON AND SPEARMINT OIL EXTRACTS ON THE SPINY BOLLWORM, EARIAS INSULANA (BOISD.)
}

\author{
HEGAB , M. E. M. A. \\ Plant Protection Research Institute, ARC, Dokki, Giza, Egypt. \\ (Manuscript received 24 December 2017)
}

\begin{abstract}
$\mathrm{L}$ aboratory experiments were conducted at Plant Protection Research Institute (Sharkia branch), Bollworms Research Department to evaluate the toxicity of two medicinal plant extracts i.e. lemon, Citrus limon (L.) and spearmint, Mentha spicata (Briq.) oils against the spiny bollworm, Earias insulana (Boisd.). The $\mathrm{LC}_{50}, \mathrm{LC} 90$ for both extracts after 24 hours were determined. Moreover, the effects of lemon and spearmint oils on some biological and physiological aspects of the SBW were studied. The obtained results showed that C. limon and M. spicata oils had toxic effect against newly hatched larvae of $E$. insulana. The $\mathrm{LC}_{50}, \mathrm{LC}_{90}$ values were $0.033,0.2418$ for $C$. limon, and $0.0007,0.1597 \mathrm{ppm}$ for the M. spicata, respectively. For lemon, the mortality percentage recorded $78.67,71.33,65.33$ and $24.00 \%$ for $1^{\text {st }}$ instar larvae at concentration $0.150,0.0750,0.0375$ and $0.0156 \mathrm{ppm}$. While mortality percentage for spearmint extract was $80.00,77.42$, 75.94 and $62.59 \%$ at concentration of $0.0325,0.0162,0.0081$ and $0.0040 \mathrm{ppm}$, respectively. Also, the spearmint oil was more toxic than Lemon oil. Otherwise, treatment with both oils caused pronounced short larval duration, pupal period, adult longevity, oviposion periods; larval and pupal weight, pupation and sex ratio percentages. Both oils significantly reduced adults fecundity and eggs hatchability percentage compared to control. On the other hand, adult moths fed on C. limon and Mentha spicata oils decreased oviposion periods compared to untreated adults. Additionally, it exhibited reduction in the numbers of laid eggs, while, in case of M. spicata the higher concentrations caused infertility for female moths compared to control. The results of the physiologic analysis showed a significant decrease in some biological characteristics of the spiny bollworm, especially the weight of the larvae and pupae, the number of eggs and the hatching rate. The results showed the changes in the activity of carbohydrate enzymes in the spiny bollworm larvae treated with $C$. limon and M. spicata was a significant increase in amylase and trehalase, aspirate amino transferase (AST) enzymes and total soluble protein contents in the spiny bollworm larvae treated with C. limon and M. spicata compared to control. While, the invertase, alanine amino transferase (ALT) and acetylcholinestriase (AChE) enzyme fluctuated from negative to positive activity up to the oil concentration compared to control. In conclusion, the lemon and spearmint oils could be tested in semi-field and field experiments to clarify its role in reduction infestation of SBW in cotton fields especially at the low infestation in the begging of cotton season and then incorporated into integrated control programs as one of vital factors for control the spiny bollworm.
\end{abstract}


Key words: Plant extracts, Spiny bollworm, SBW, Earias insulana, Lemon, Citrus limon, Spearmint, Mentha spicata, Toxicity, Biology and Biochemical.

\section{INTRODUCTION}

The spiny bollworm, Earias insulana (Boisd.) is one of the most important economic insect pests in Egypt and all over the world (Abdel-Salam, and Negm 2009). Villafañe et al. (2011) stated that C. limon oil influence on the Spodoptera frugiperda larvae, pupal mortalities and cause mortality and antifeedant action. On the other hand, the essential oils from Mentha spicata were carvone d-limonene and dihydrocarvone as major constituents out of the 21 components spearmint compounds contained more properties: antifungal, antiviral, antimicrobial, insecticidal, antioxidant, antiallergic, diuretic and stimulating (Ioan et al., 2014). The activity of GOT and GPT enzymes of trehalase, invertaze and amylase activities and the total soluble protein in larvae of pink and spiny bollworms were studied after treatment with garlic extract. Previously, many researchers reported that achetylcholine (AChE) has a key role in neurotransmitter by hydrolyzing the neurotransmitter in cholinergic synapses of the nervous system and is the target site of several neurotoxic insecticides Amer (2004).

Therefore, this study aimed to evaluate the toxicity of two natural plant extracts: Citrus limon and Mentha spicata against $1^{\text {st }}$ instar larvae and adult stage of the spiny bollworm, Earias insulana. The study also, involved the effects of the previous compounds on some physiological aspects and biochemical parameters of the insect.

\section{MATERIALS AND METHODS}

\section{The plant extracts:}

A. Lemon, Citrus limon (L.) oil (Order: Sapindales, Fam.: Rutaceae) A commercial formulation form was purchased from EL-Captain Company, Egypt.

The amount for lemon oil, D-limonene (64\%), 2-cyclohexen-1-ol (6.21\%) and $\beta$ Pinene (3.822\%) (Njoku and Evbuomwan 2014).

B. The leaves of Spearmint, Mentha spicata subsp. condensate (Briq.) (Order: Lamiales) Fam.: Lamiaceae) that collected from Sharkia Governorate, Egypt were air dried at room temperature. Essential oil was extracted from the leaves of M. spicata. The spearmint leaves extract was prepared in study as follows:

The essential oil was extracted by steam distillation for 4-6 $h$, using a Clevenger-type apparatus (Clevenger, 1928) where $300 \mathrm{gm}$ of plant materials in 300 $\mathrm{ml}$ of water subjected to hydro distillation (Marcus and Lichtenstein, 1979). The oil 
was separated, dried over anhydrous sodium sulfate $\mathrm{Na}_{2} \mathrm{SO}_{4}$ and stored in dark glass bottles at $4^{\circ} \mathrm{C}$ in the refrigerator until used.

The essential oil from M. spicata contains carvone (73.29 \%), d-limonene (7.59 $\%)$ and dihydrocarvone (3.83 \%) as major constituents out of the 21 components. The essential oil from M. cardiaca contains carvone (60.9\%) and limonene (21.58 \%) as major constituents out of the 35 components (Chowdhury et al., 2007).

2. Insect Rearing Technique: To evaluate the effects of $C$. limon and $M$. spicata oils on the $E$. insulana larvae (SBW). A batch of SBW larvae was obtained from Bollworms Research Department, Plant Protection Research Institute, Sharkiya Branch, (ARC). This strain was collected from cotton field and reared in an incubator at $26 \pm 1^{\circ} \mathrm{C}$ and $80 \pm 5 \%$ R.H. on a modified artificial diet as described previously by (Amer, 2015) for many generations free from any insecticide contamination.

3. Plant extracts processing: To evaluate the toxic effect of the two tested plant extracts against newly hatched larvae of $E$. insulana, serial aqueous dilutions of $C$. limone \& M. spicata were prepared $(0.150,0.0750,0.0375$ and $0.0156 \mathrm{ppm})$ \& $(0.0325,0.0162,0.0081$ and $0.0040 \mathrm{ppm})$ using distilled water and add some drops of Triton $B$ as an emulsifier, respectively.

\section{Bioassay tests:}

4. a. The procedure: Ten grams of artificial diet was putted in a Petri-dish $(9 \mathrm{~cm}$ in diameter) and one $\mathrm{ml}$ of the tested concentration was distributed on the surface of the diet and left until dryness. Each concentration was replicated three times. Twenty five of newly hatched larvae of SBW of each replicate were transferred to the surface of treated diet using a soft brush and kept at $26 \pm 1^{\circ} \mathrm{C}$ and $80 \pm 5 \% \mathrm{R}$. H. at an electrical incubator. Similar number of larvae was transferred into untreated diet. Larvae were allowed to feed on the tested diets for 24 hours. Percentages of mortalities were recorded and corrected according to Abbott's formula (1925) as follows: \%Corrected mortality $=\frac{\mathrm{T}-\mathrm{C}}{100-\mathrm{C}} \times 100$

Where: $\quad \mathrm{T}: \%$ mortality in treatment C: \%mortality in check

The $\mathrm{LC}_{50}, \mathrm{LC}_{90}$ and the slope values were determined according to (Finney, 1971).

After 24 hours from treatment any alive larvae were transferred individually to glass tubes $(2.0 \times 7.0 \mathrm{~cm})$ containing $3.0 \mathrm{gm}$ of control diet. Tubes were plugged with absorbent cotton and incubated at aforementioned conditions for ten days. The tubes were inspected daily and larval mortalities were recorded. Larval mortality percentage, larval and pupal duration, larval and pupal weight, pupation percentage, sex ratio 
percentages were recorded. Newly emerged moths of SBW were sexed and paired into glass Jars (250 $\mathrm{ml}$ in size) 3pairs/ glass Jars for mating. The upper and lower surfaces of each were covered with muslin cloth held in position by rubber bands. Three replicates/ conc. / extract were used. The emerged moths were fed on $10 \%$ sucrose solution, as well as, control by providing each cage with soaked piece of cotton wool. (Each Jar was inspected daily to record the number of deposited eggs/ female till death, the oviposition periods, longevity of males and females, the number of deposited eggs / female and hatchability percentages.

4. b. Moths feeding test: This experiment was directed to evaluate the effect of the three concentrations of Citrus limon oil $(0.15,0.075$ and $0.0375 \mathrm{ppm})$ and $(0.0325,0.0162$ and $0.0081 \mathrm{ppm})$ concentrations of Mentha spicata oil on $E$. insulana (SBW) moths. Pairs of emerged adult moths', were placed in glass chimney for mating. The upper and lower surfaces of each were covered with muslin cloth held in position by rubber bands. Moths were fed by providing each cage with soaked piece of cotton wool in $10 \%$ sugar solution only as control. The cages were kept under the previous condition. Treatment the alive and dead moths were recorded after 24 hrs. The cages were inspected daily until moth death. Pre-oviposition, oviposition and post-oviposition periods, female \& male longevity, number of deposited eggs/female and hatchability percentages were recorded.

\section{Biochemical effects of C. limon and M. Spicata on larvae of spiny bollworm:}

The present experiment was designed to study the changes in the activities of the major biochemical components, which are necessary for organism development, and perform its vital activities: carbohydrate hydrolyzing enzymes, total soluble protein and transaminas enzymes (AST\& ALT) and acetylcholine eateries (AchE) in the supernatant of the homogenate of the spiny bollworm larvae as affected by different concentrations of $C$. limon and M. Spicata oils $(0.150$ and 0.0750 ppm \& 0.0325 and $0.0162 \mathrm{ppm}$, respectively) as compared to untreated larvae (control).

5. 1. The preparation of samples: Newly hatched larvae were allowed to feed on artificial diet treated with $(0.150$ and $0.0750 \mathrm{ppm} \& 0.0325$ and $0.0162 \mathrm{ppm}$, of $C$. limon and M. Spicata oils, respectively for 24 hours and then transferred to feed on untreated diet. Seven days after treatment. Twenty larvae from each treatment and control were placed in clean Jars and left four hours to starve. The starved larvae were homogenized in distilled water (1 larvae: $1 \mathrm{ml}$ ) using a Teflon homogenizer surrounded with jacket of crushed ice for three minutes. The homogenate larvae were centrifuged at 3500 R.P.M. for 10 minutes at $5^{\circ} \mathrm{C}$. The supernatant was immediately 
assayed to determine amylase, invertase, trehalase, (AST) \& (ALT) enzymes, total soluble protein and acetylcholinesterase (AchE) activities.

a. Carbohydrate hydrolyzing enzymes: The methods used to determine the activities of amylase, invertase and trehalase enzymes according to (Ishaaya and Swiriski, 1976).

The activities of AST and ALT enzymes were determined calorimetrically according to the method of (Reiteman and Frankle 1957).

b. Determination of total soluble protein: Colorimetric determination of total soluble protein in total homogenate of larvae of spiny bollworm was carried out as described by (Gornall et al., 1949).

\section{c. Enzymes measurements:}

Acetylcholinesterase (AchE) activity: Acetylcholinesterase was measured according to the method described by (Simpson et al., 1964).

6-Statistical analysis: The obtained data were statistically analyzed. Toxicological data were statistically calculated through a Proban program, software computer program (Jedrychowski, 1991). The proper "F" and LSD value was calculated as described by (Fisher, 1944) using Costat program software computer.

\section{RESULTS}

\section{Toxicity of the two oils:}

Results in Table (1) showed that the $L C_{50}$ and $L C_{90}$ values were 0.033 and 0.2418 ppm for $1^{\text {st }}$ instar larvae of (SBW) treated with C. limon oil, while it gave 0.0007 and $0.1597 \mathrm{ppm}$ for $M$. Spicata oil, respectively. The $1^{\text {st }}$ instar larvae of SBW was highly susceptible for M. spicata than C. limon oils. (Amani et al., 2015) proved that Ocimum basilieum (L.) had toxic effect against newly hatched larvae of $E$. insulana. The LC 50 and $L C_{90}$ values of basil oil against SBW larvae were 41.34 and 178.76 ppm.

Table 1 . Toxicity of $C$. limon and $M$. spicata oils against $E$. insulana $1^{\text {st }}$ instar larvae

\begin{tabular}{|c|c|c|c|}
\multicolumn{5}{c|}{ insect } & $\mathrm{LC}_{50}$ & $\mathrm{LC}_{90}$ & Slope \\
\hline Plant oils & 0.033 & 0.2418 & 1.4811 \\
\hline Citrus limon & 0.033 & 0.1597 & 0.5485 \\
\hline Mentha spicata & 0.0007 & 0 \\
\hline
\end{tabular}

\section{Effect of $C$. limon and $M$. spicata on some biological aspects of the $1^{\text {st }}$} instar larvae of spiny bollworm:

Larval mortality percentage: Data in Table (2) indicated highly significant differences between larval moralities of SBW treated with different concentrations of 
C. limon and M. spicata concentrations compared with untreated check. Increased concentrations from each oils increased progressively larval mortality percentage.

Larval duration: Results indicated that no significant differences was found between larval duration of SBW treated with different concentrations of the two oils compared to untreated check (Table 2).

Larval weight: Table (2) show that no significant differences were found between the tested concentrations of the oils as compared with the control. The lowest tested concentration of $C$. limon and $M$. spicata oils caused a decreases in larval weight as compared to the control.

Pupal period: The results in Table (2) showed that all concentrations of $C$. limon led to shorten the SBW pupal period significant compared with the untreated check.

Pupal weight: Also, C. limon and M. spicata oils caused no significant \& significant effect on pupal weight of SBW by raising concentrations as compared with control (Table 2).

Pupation percentage: Results in Table (2) indicate that pupation percentages of SBW decreased with increasing of $C$. limon and $M$. spicata oils as compared with control.

Adult stage: C. limon and M. spicata plant extracts caused significant effect in sex ratio of SBW with the two tested oils, respectively, compared with control. In case of pre - and oviposition periods the results in Table (3) showed that the tested concentrations indicated no significant effect and significant effect of post- oviposition periods compared to untreated check. Also, results showed that C. limon and $M$. spicata plant extracts shorten adult longevity than control. The tested oils significantly reduce numbers of laid eggs and the hatchability percentages compared with check. The rate of hatchability \% was increased with concentration decreased in each oil and 
Table 2. Effect of different concentrations of $C$. limon and M. spicata oils on immature stages of $E$. insulana under laboratory conditions

\begin{tabular}{|c|c|c|c|c|c|c|c|}
\hline Plant oils & $\begin{array}{c}\text { Concentrations } \\
\text { ppm }\end{array}$ & $\begin{array}{c}\text { Larval } \\
\text { Mortality } \\
\%\end{array}$ & $\begin{array}{l}\text { Larval } \\
\text { duration } \\
\text { (days) }\end{array}$ & $\begin{array}{c}\text { Larval } \\
\text { Weight (g) }\end{array}$ & $\begin{array}{l}\text { Pupal } \\
\text { Period } \\
\text { (days) }\end{array}$ & $\begin{array}{c}\text { Pupal } \\
\text { Weight (g) }\end{array}$ & Pupation \% \\
\hline \multirow{7}{*}{ 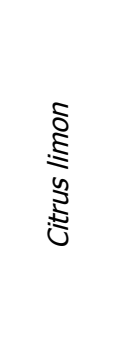 } & 0.150 & $78.67^{a}$ & 12.25 & 0.0432 & $5.16^{\mathrm{b}}$ & 0.0324 & $21.33^{e}$ \\
\hline & 0.0750 & $71.33^{\mathrm{a}}$ & 13.75 & 0.0461 & $5.18^{\mathrm{b}}$ & 0.0306 & $29.33^{d}$ \\
\hline & 0.0375 & $65.33^{b}$ & 14.42 & 0.0483 & $7.75^{\mathrm{ab}}$ & 0.0315 & $34.67^{c}$ \\
\hline & 0.0156 & $24.00^{c}$ & 14.00 & 0.0588 & $8.82^{\mathrm{ab}}$ & 0.0426 & $76.00^{b}$ \\
\hline & Control & $0.00^{d}$ & 16.14 & 0.0685 & $11.21^{\mathrm{a}}$ & 0.0504 & $97.33^{\mathrm{a}}$ \\
\hline & P & $\begin{array}{c}0.000 \\
* * *\end{array}$ & 0.3866 N.S. & $\begin{array}{l}0.3776 \\
\text { N.S. }\end{array}$ & 0.0159* & $\begin{array}{l}0.5470 \\
\text { N.S. }\end{array}$ & $\begin{array}{c}0.000 \\
* * *\end{array}$ \\
\hline & $\mathrm{LSD}_{0.05}$ & 5.10 & & & 4.43 & & 4.23 \\
\hline \multirow{7}{*}{ 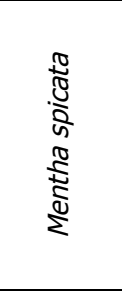 } & 0.0325 & $80.00^{\mathrm{a}}$ & 13.30 & 0.0432 & $7.25^{b}$ & $0.030^{\mathrm{b}}$ & $18.66^{d}$ \\
\hline & 0.0162 & $77.42^{\mathrm{a}}$ & 13.67 & 0.0556 & $6.33^{b}$ & $0.0435^{\mathrm{ab}}$ & $22.67^{b}$ \\
\hline & 0.0081 & $75.94^{a}$ & 13.75 & 0.0562 & $7.38^{\mathrm{b}}$ & $0.0427^{\mathrm{ab}}$ & $28.00^{c}$ \\
\hline & 0.0040 & $62.59^{b}$ & 14.20 & 0.0610 & $8.05^{b}$ & $0.0536^{\mathrm{ab}}$ & $37.33^{b}$ \\
\hline & Control & $0.00^{c}$ & 16.45 & 0.0718 & $10.89^{\mathrm{a}}$ & $0.0640^{\mathrm{a}}$ & $98.67^{\mathrm{a}}$ \\
\hline & P & $\begin{array}{c}0.000 \\
* * *\end{array}$ & 0.5849 N.S. & $\begin{array}{l}0.5527 \\
\text { N.S. }\end{array}$ & $0.1341 *$ & $0.2667 *$ & $\begin{array}{c}0.000 \\
* * *\end{array}$ \\
\hline & LSD $_{0.05}$ & 6.30 & & & 3.06 & 0.0325 & 4.07 \\
\hline
\end{tabular}

$*=$ Significant $* *=$ Highly significant

Within the same column and source data followed by the same letter are not significantly different ( $P>0.05$; LSD mean separately).

Table 3. Effect of $C$. limon and M. spicata oils on mature stages of the spiny bollworm.

\begin{tabular}{|c|c|c|c|c|c|c|c|c|c|c|}
\hline \multirow{2}{*}{\begin{tabular}{c|} 
\\
Plant \\
oils
\end{tabular}} & \multirow{2}{*}{$\begin{array}{c}\text { Concentrations } \\
\mathrm{ppm}\end{array}$} & \multicolumn{2}{|c|}{ Sex ratio \% } & \multicolumn{3}{|c|}{ Oviposition period/female(days) } & \multicolumn{2}{|c|}{$\begin{array}{c}\text { Adult } \\
\text { longevity(days) }\end{array}$} & \multirow{2}{*}{ 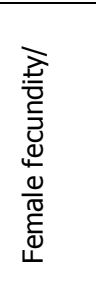 } & \multirow{2}{*}{ 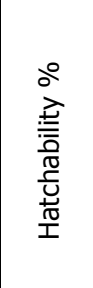 } \\
\hline & & $\begin{array}{c}\text { Female } \\
\wp\end{array}$ & $\begin{array}{c}\text { Male } \\
\sigma^{*}\end{array}$ & $\begin{array}{c}\text { Pre- } \\
\text { oviposition } \\
\text { Period }\end{array}$ & $\begin{array}{c}\text { Oviposition } \\
\text { period }\end{array}$ & $\begin{array}{c}\text { Post- } \\
\text { oviposition } \\
\text { period }\end{array}$ & $\begin{array}{c}\text { Female } \\
\wp\end{array}$ & $\begin{array}{c}\text { Male } \\
0^{x}\end{array}$ & & \\
\hline \multirow{7}{*}{$\begin{array}{l}\text { Citrus } \\
\text { Limon }\end{array}$} & 0.150 & $50.00^{\mathrm{ab}}$ & $50.00^{\mathrm{bc}}$ & 2.00 & 5.00 & $1.50^{\mathrm{b}}$ & $8.50^{\mathrm{b}}$ & 11.50 & $9.75^{a}$ & $13.02^{\mathrm{d}}$ \\
\hline & 0.0750 & $53.38^{\mathrm{a}}$ & $46.62^{b c}$ & 2.50 & 5.50 & $1.70 \mathrm{~b}$ & $9.70^{\mathrm{b}}$ & 12.50 & $44.50^{c}$ & $64.55^{\mathrm{ab}}$ \\
\hline & 0.0375 & $44.44^{\mathrm{bc}}$ & $48.89^{a b}$ & 3.25 & 6.00 & $2.00^{b}$ & $11.25^{\mathrm{b}}$ & 12.25 & $84.50^{\mathrm{b}}$ & $70.20^{c}$ \\
\hline & 0.0156 & $42.30^{c}$ & $57.70^{\mathrm{a}}$ & 3.30 & 6.38 & $2.25^{b}$ & $11.93^{b}$ & 10.75 & $92.75^{b}$ & $79.00^{\mathrm{ab}}$ \\
\hline & Control & $46.37^{\mathrm{bc}}$ & $53.63^{\mathrm{ab}}$ & 4.12 & 6.25 & $6.21^{\mathrm{a}}$ & $16.58^{\mathrm{a}}$ & 12.11 & $23.00^{\mathrm{a}}$ & $94.00^{a}$ \\
\hline & $\mathrm{P}$ & $0.0129 *$ & $0.0129 *$ & $\begin{array}{c}0.2965 \\
\text { N.S. }\end{array}$ & $\begin{array}{c}0.6636 \\
\text { N.S. }\end{array}$ & $0.0053 *$ & $0.0015^{*}$ & 0.850 N.S & $\begin{array}{c}0.000 \\
* * *\end{array}$ & $\begin{array}{c}0.0009 \\
* * *\end{array}$ \\
\hline & $\mathrm{LSD}_{0.05}$ & 5.92 & 5.92 & & & 2.30 & 3.82 & & 13.40 & 28.98 \\
\hline \multirow{7}{*}{$\begin{array}{l}\text { Mentha } \\
\text { spicata }\end{array}$} & 0.0325 & $66.67^{\mathrm{a}}$ & $33.33^{b}$ & 2.50 & 8.00 & $2.00^{\mathrm{b}}$ & 12.50 & 11.00 & $64.00^{d}$ & $12.81^{\mathrm{C}}$ \\
\hline & 0.0162 & $54.55^{\mathrm{bc}}$ & $45.45^{b}$ & 3.00 & 7.50 & $2.75^{\mathrm{ab}}$ & 13.25 & 11.50 & $70.75^{d}$ & $44.30^{\mathrm{b}}$ \\
\hline & 0.0081 & $56.25^{\mathrm{bc}}$ & $43.75^{b}$ & 4.34 & 8.22 & $3.00^{\mathrm{ab}}$ & 14.56 & 12.00 & $108.72^{c}$ & $79.24^{a}$ \\
\hline & 0.0040 & $40.00^{c}$ & $60.00^{\mathrm{a}}$ & 4.50 & 8.00 & $3.50^{\mathrm{ab}}$ & 16.00 & 13.75 & $114.67^{c}$ & $81.02^{\mathrm{a}}$ \\
\hline & Control & $57.78^{\mathrm{ab}}$ & $42.22^{\mathrm{b}}$ & 4.63 & 7.60 & $4.37^{a}$ & 16.60 & 14.25 & $245.00^{\mathrm{a}}$ & $92.00^{a}$ \\
\hline & $\mathrm{P}$ & $\begin{array}{c}0.0173 \\
* * * \\
\end{array}$ & $\begin{array}{c}0.0138 \\
* * *\end{array}$ & $\begin{array}{l}0.3779 \\
\text { N.S. }\end{array}$ & $\begin{array}{l}0.9686 \\
\text { N.S. }\end{array}$ & $0.0890 *$ & $\begin{array}{l}0.8068 \\
\text { N.S. }\end{array}$ & $\begin{array}{l}0.4953 \\
\text { N.S. }\end{array}$ & $\begin{array}{l}0.000 \\
* * * * \\
\end{array}$ & \begin{tabular}{|l|}
0.000 \\
$* * *$ \\
\end{tabular} \\
\hline & $\mathrm{LSD}_{0.05}$ & 16.27 & 13.02 & & & 1.79 & & & 23.01 & 16.12 \\
\hline
\end{tabular}

NS=Non-significant $\quad *=$ Significant $\quad * *=$ Highly significant

Within the same column and source data followed by the same letter are not significantly different

( $P>0.05$; LSD mean separately).

3. Moths feeding test: The tested concentrations showed no significant \& significant effect on pre-oviposion period for $C$. limon and M. spicata oils compared to 
control. The tested concentrations of $C$. limon and M. spicata indicated significant effect on oviposition and post oviposition periods compared with check. In addition, results show that increasing the concentration of the tested oils induced a reduction in numbers of laid eggs i.e. decreasing the concentration increasing laid eggs and \% hatchability compared with control. In case of $C$. limon oil, the lowest rate of hatchability achieved $50.69 \%$ in the highest concentration compared with $95.00 \%$ in untreated moth Table (4). While, in case of M. spicata, infertile moths appeared in the highest concentration with no laying eggs compared with control Table (4).

Table 4. Effect of Citrus limon and Mentha spicata oils on Earias insulana moths.

\begin{tabular}{|c|c|c|c|c|c|c|c|c|}
\hline \multirow{2}{*}{$\begin{array}{l}\frac{n}{0} \\
\overline{\overline{0}} \\
\frac{\mathrm{T}}{\alpha}\end{array}$} & \multirow{2}{*}{ 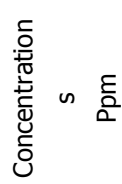 } & \multicolumn{3}{|c|}{ Oviposion periods/ days } & \multicolumn{2}{|c|}{$\begin{array}{c}\text { Adult longevity / } \\
\text { days }\end{array}$} & \multirow[t]{2}{*}{$\begin{array}{l}\text { Female } \\
\text { fecundity }\end{array}$} & \multirow[t]{2}{*}{ Hatchability \% } \\
\hline & & Pre & Ovi & Post & $\begin{array}{c}\text { Female } \\
\wp\end{array}$ & Maleơ & & \\
\hline \multirow{6}{*}{$\begin{array}{l}\stackrel{\delta}{\delta} \\
ن\end{array}$} & 0.150 & 3.00 & $8.00^{\mathrm{b}}$ & $2.00^{\mathrm{a}}$ & 12.00 & 14.30 & $73.94^{c}$ & $50.69^{d}$ \\
\hline & 0.0750 & 3.52 & $9.08^{\mathrm{ab}}$ & $3.75^{\mathrm{ab}}$ & 16.35 & 15.18 & $111.50^{\mathrm{b}}$ & $58.84^{\mathrm{cd}}$ \\
\hline & 0.0375 & 4.00 & $10.50^{\mathrm{a}}$ & $5.50^{\mathrm{a}}$ & 20.00 & 15.30 & $128.00^{\mathrm{b}}$ & $72.30^{\mathrm{bc}}$ \\
\hline & Control & 4.50 & $6.83^{b}$ & $4.90^{\mathrm{a}}$ & 20.00 & 15.18 & $202.66^{a}$ & $95.00^{\mathrm{a}}$ \\
\hline & $P$ & $\begin{array}{l}0.7691 \\
\text { N.S. }\end{array}$ & $0.1590 *$ & $0.0340 *$ & $\begin{array}{l}0.2908 \\
\text { N.S. }\end{array}$ & $\begin{array}{l}0.9441 \\
\text { N.S. }\end{array}$ & $\begin{array}{l}0.000 \\
* * *\end{array}$ & $\begin{array}{c}0.001 \\
* *\end{array}$ \\
\hline & $\operatorname{LSD}_{0.05}$ & & 3.39 & 2.30 & & & 16.59 & 16.79 \\
\hline \multirow{6}{*}{ 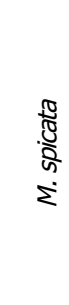 } & 0.0325 & $0.00^{\mathrm{b}}$ & $0.00^{\mathrm{b}}$ & $0.00^{\mathrm{b}}$ & $3.25^{\mathrm{c}}$ & $4.50^{c}$ & $0.00^{c}$ & $0.00^{\mathrm{b}}$ \\
\hline & 0.0162 & $0.00^{\mathrm{b}}$ & $0.00^{\mathrm{b}}$ & $0.00^{\mathrm{b}}$ & $4.50^{c}$ & $8.00^{b c}$ & $0.00^{c}$ & $0.00^{\mathrm{b}}$ \\
\hline & 0.0081 & $4.00^{\mathrm{a}}$ & $8.50^{\mathrm{a}}$ & $3.75^{\mathrm{a}}$ & $13.30^{\mathrm{b}}$ & $11.75^{\mathrm{ab}}$ & $43.63^{b}$ & $82.11^{a}$ \\
\hline & Control & $5.50^{\mathrm{a}}$ & $7.50^{\mathrm{a}}$ & $5.20^{\mathrm{a}}$ & $18.20^{\mathrm{a}}$ & $15.70^{\mathrm{a}}$ & $220.00^{\mathrm{a}}$ & $93.60^{\mathrm{a}}$ \\
\hline & $P$ & $\begin{array}{l}0.005 \\
* * *\end{array}$ & $0.000 * *$ & $\begin{array}{l}0.000 \\
* * *\end{array}$ & $\begin{array}{l}0.000 * \\
* *\end{array}$ & $\begin{array}{l}0.0024 \\
* * *\end{array}$ & $\begin{array}{l}0.000 \\
* * *\end{array}$ & $\begin{array}{l}0.000 \\
* * *\end{array}$ \\
\hline & LSD $_{0.05}$ & 2.11 & 2.11 & 2.10 & 3.77 & 4.51 & 13.31 & 13.30 \\
\hline
\end{tabular}

NS=non-significant $*=$ significant $* *$ highly significant

Within the same column and source data followed by the same letter are not significantly different $(P>0.05$; LSD mean separately).

\section{Biochemical effect of $C$. limon and $M$. spicata oils on the $1^{\text {st }}$ instar larvae}

of spiny bollworm: Data in Table (5) refer to the changes in the activity of carbohydrate hydrolyzing enzymes of $E$. insulana at seven days old larvae. The activity of amylase, trehalase, AST enzymes and total soluble protein were highly positively increased than control but invertase, ALT negatively activity appeared in most concentrations except the low one $(7.50 \%)$ in C. limon. The actylecholinesterase (AChE) showed positively activity in high concentrations of both oils and vise versa (negatively activity) in low concentration of each oil than control (Table 5). 
Table 5. Changes in activities of some enzymes, total soluble protein and acetylcolin esterase in the supernatant of the homogenated of spiny bollworm larvae as affected by C. limon and M. spicata oils

\begin{tabular}{|c|c|c|c|c|c|c|c|c|c|c|c|c|c|c|c|}
\hline \multirow[b]{2}{*}{$\begin{array}{l}\frac{0}{\overline{\bar{O}}} \\
\stackrel{\underline{\underline{L}}}{\frac{\pi}{\alpha}}\end{array}$} & \multirow[b]{2}{*}{ 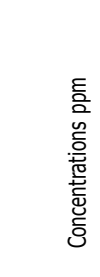 } & \multicolumn{6}{|c|}{ Carbohydrate hydrolyzing enzymes $\mathrm{mg}$ carbohydrates/g b.wt } & \multicolumn{4}{|c|}{ Transaminase enzymes } & \multirow{2}{*}{$\begin{array}{c}\text { Total } \\
\text { Soluble } \\
\text { Protein } \\
\text { mg protein } \\
\text { /g b.wt. }\end{array}$} & \multirow[b]{2}{*}{ 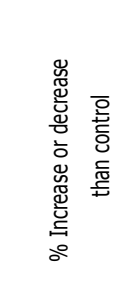 } & \multirow[b]{2}{*}{ AChE } & \multirow{2}{*}{ 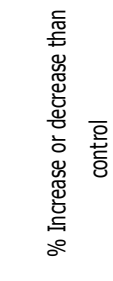 } \\
\hline & & 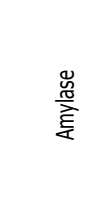 & 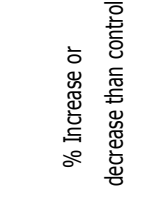 & 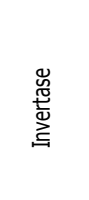 & 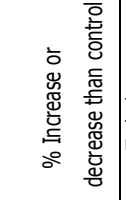 & 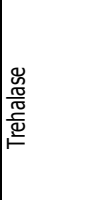 & 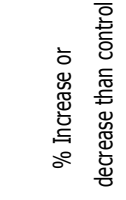 & AST & 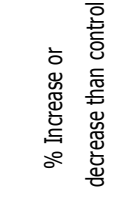 & ALT & 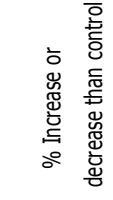 & & & & \\
\hline \multirow{2}{*}{ 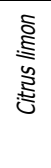 } & 0.150 & $124.03 a$ & +276.53 & $52.14 \mathrm{c}$ & -34.69 & $46.44 a$ & +124.02 & $5.78 \mathrm{c}$ & +16.77 & $64.42 a$ & +43.35 & $16.49 a$ & +102.37 & $606.448 a$ & +132.84 \\
\hline & 0.0750 & 37.33d & +13.33 & $149.84 \mathrm{a}$ & +87.67 & $23.25 \mathrm{c}$ & +12.16 & $31.44 a$ & +535.15 & $30.52 \mathrm{c}$ & -32.09 & $10.083 \mathrm{~b}$ & +23.67 & $186.178 \mathrm{e}$ & -28.52 \\
\hline \multirow{2}{*}{ 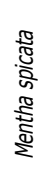 } & 0.0325 & $46.93 c$ & +42.47 & $51.44 c$ & -35.57 & 46.93a & +126.39 & $34.03 a$ & +587.47 & $64.06 a$ & +42.55 & 14.601ab & +79.09 & $482.044 b$ & +85.08 \\
\hline & 0.0162 & $65.26 b$ & +98.12 & $23.66 \mathrm{~d}$ & -70.37 & $37.24 b$ & +79.64 & $13.10 \mathrm{~b}$ & +164.65 & $11.44 d$ & -74.54 & $11.67 a b$ & +43.14 & $192.283 d$ & -26.17 \\
\hline \multicolumn{2}{|c|}{ Control } & $32.94 \mathrm{~d}$ & & $79.84 b$ & & $20.73 c$ & & $4.95 \mathrm{c}$ & & $44.94 b$ & & 8.153b & & $260.456 \mathrm{c}$ & \\
\hline \multicolumn{2}{|c|}{ F. test } & $* *$ & & ** & & ** & & ** & & ** & & * & & ** & \\
\hline \multicolumn{2}{|c|}{$\operatorname{LSD}_{0.05}$} & 6.91 & & 6.50 & & 7.91 & & 4.49 & & 6.59 & & 6.57 & & 5.57 & \\
\hline
\end{tabular}

** Highly significant within the same column and source data followed by the same letter are not significantly different ( $P>0.05$; LSD mean separately).

$\%$ Increase or decrease than control $=$ treated - control $\div$ control $\times 100$.

$\mathrm{AST}=$ Aspartate aminotransferase $\mathrm{ALT}=$ Alanine aminotransferase $\mathrm{AchE}=$ Acetylcolinesterase 


\section{DISCUSSION}

The effect of lemon, Citrus limon (L.) and spearmint, Mentha spicata (Briq.) oils on some biological aspects of the spiny bollworm, Earias insulana (Boisd.). The results indicated that both oils proved toxic effects against $E$. insulana. M. spicata was more toxic than $C$. limon oil. Larval mortality percentages were increased as concentration increased after ten days from treatment compared with the untreated check. Both extracts caused pronounced short larval duration, pupal period, pupation percentages, adult longevity, oviposion periods; larval and pupal weight, and sex ratio and reduce the fecundity and hatchability percentages. Adult moth fed on C. limon and M. spicata oils decreased oviposion periods, adult longevity and the numbers of laid eggs compared to untreated check. While, in case of $M$. spicata the highest concentration showed infertile moths with no laying eggs compared with control. Also, it was found that the two oils reduced the hatchability percentages compared with untreated moths. The results showed that the change in the activity of carbohydrate enzymes in the spiny bollworm larvae treated with $C$. limon and $M$. spicata induced a significant increase in amylase and trehalase, AST enzymes and total soluble protein contents. The invertase, ALT and acetylcholinestriase (AChE) enzyme were fluctuated from negative to positive activity up to the oil concentration compared to control.

The present results are in agreement with (Villafañe et al., 2011) who found that the essential oils of $C$. aurantium and $C$. limon were more effective on Spodoptera frugiperda. (Amani et al., 2015) stated that basil oil Ocimum basilieum (L.) significantly prolonged larval and pupal duration and decreased pupation and adult emergence percentages of $E$. insulana. (Amer, 2004) reported that decrease in the activity of GOT and GPT enzymes and increasing of trehalase, invertase and amylase activities as well as in the total soluble protein of pink and spiny bollworms larvae after treatment with garlic extract.

\section{REFERENCES}

1. Abbott, W. S. 1925. A method of computing the effectiveness of an insecticide. J. Econ. Entomol. 18 (2): 265- 267.

2. Abdel-Salam, M. E. and M. A. M. E. Negm. 2009. The Egyptian Cotton; current constraints and future opportunities Publisher: Textile Industries Holding Co. Modern Press- Alexandria-Egypt. Agric. Agric. Res. Serv., USDA. Hand Book.8:190.

3. Amani, M. D. El -Mesallamy; S. A. Raslan; M. E. Nagar and A. Z. Warda ElMedany. 2015. Toxicological and biological effect of Ocimum basilicum L. oil on some cotton pests. Middle East J. Agric., 4 (4): 949-955.

4. Amer, A. E. A. 2004. Ecological and physiological studies on bollworms. Ph. D. Thesis, Fac. of Agric., Moshtohor Branch, Zagazig Univ., Egypt. 213 pp. 
5. Amer, A. E. A. 2015. Economic artificial diets for rearing spiny bollworm, Earias insulana (Boisd.) (Lepidoptera: Noctuidae). J. Plant Prot. and Path., Mansoura Univ., 6 (3): 527-534.

6. Chowdhury, J. U; N, N. Chandra; M. Uddin and M. Rahman. 2007. Chemical Constituents of Essential Oils from Two Types of Spearmint (Mentha spicata L. and M. cardiaca L.) introduced in Bangladesh Bangladesh. J. Sci. Ind. Res. 42 (1): 79-82.

7. Clevenger, J.F. 1928. Apparatus for the determination of volatile oil. J.Am. Pharm. Assoc.; 17 (4): 345-349.

8. Finney, D. J. 1971. Probit analysis a statistical treatment of the sigmoid response curve. Cambridge Univ. Press, Cambridge: pp 333.

9. Fisher, R. A. 1944. Statistical methods for research workers. Oliver and Boyed, Edinburgh and London.

10. Gornall, A. Q.; C. J. Bradwill and M. N. David. 1949. Determination of serum proteinsby means of biuret reaction. J. Biol. Chem., 177: 751-766.

11. Ioan, C.; A. I. Gavrilă; G. C. Ivopol; M. Ivopol; N. Mircioagă; M. Buleandră; I. A. Badea and M. Pătraşcu. 2014. On the efficient extraction of essential oil from Mentha spicata. U.P.B. Sci. Bull., Series B, 76 (4): 1454 - 2331.

12. Ishaaya, I. and E. Swirski. 1976. Trehalase, invertase and amylase activities in black scale , Saissetia oleae and their relation to host adablebility, J. Ins. Physiol., (16): 1025 - 1029 .

13. Jedrychowski, R. A. 1991. Proban software program, version 1.1

14. Marcus, C. and P. Lichtenstein. 1979. Biologically active components of anise toxicity and interaction with insecticides in insects. J. Agric. Food Chemi, 27: $1217-1223$.

15. Njoku, V. I. and B.O. Evbuomwan. 2014. Analysis and ccomparative sstudy of essential oil extracted from Nigerian Orange, Lemon and Lime Peels. Greener J. Chem. Sci. and Technol. 1 (1): 006-014.

16. Reiteman, S. M. D. and S. Frankel. 1957. A colorimetric method for the determination of serum glutamic oxaloacetic acid and glutamic pyurvic transaminase. Ann. J. Clin. Pathol., 28: 56-62.

17. Simpson, D. R.; D. L. Bull and D. A. Lindquist. 1964. A semimicrotechnique for the estimation of cholinesterase activity in boll weevils. Ann. Entamol. Soc. Am., 57(3): 367-371.

18. Villafañe, E.; D. Tolosa; A. Bardón and A. Neske. 2011. Toxic effects of Citrus aurantium and $C$. limon essential oils on Spodoptera frugiperda (Lepidoptera: Noctuidae). J. Article, Res. Support, Non-U.S. Gov't Nat. Prod.Commun., 6 (9):1389-1392. 


\section{فعالية مستخلصات زيت الليمون والقلية على دودة اللوز الثوكية}

\section{محمد السبا محمد على حجاب}

معرد بحوث وقاية النباتات-الدقي -جيزة

أجريت التجارب المعملية في معهد بحوث وقاية النباتات (فرع الثرقية) قسم بحــوث ديــدان

اللوز لتقييم تأثير زيت الليمون و الفليه على بعض الجوانب البيولوجية لدودة اللوز الثوكية. أثنارت

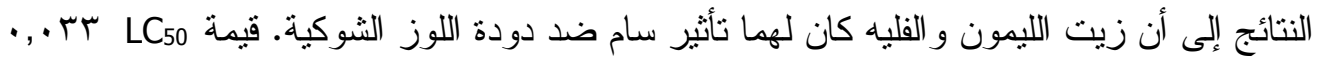

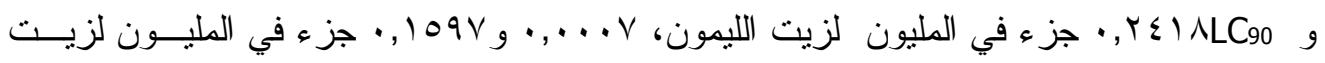

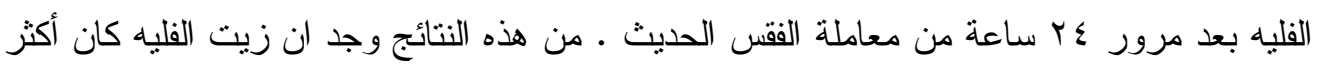

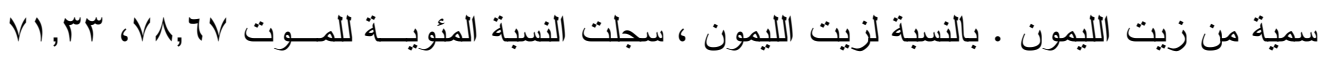

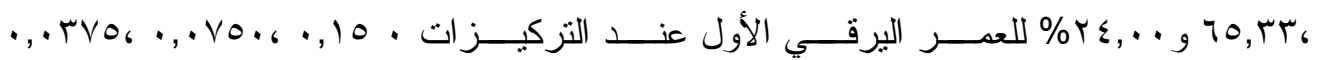

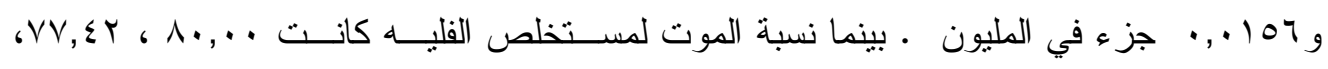
ع

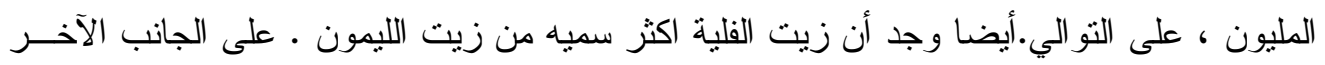

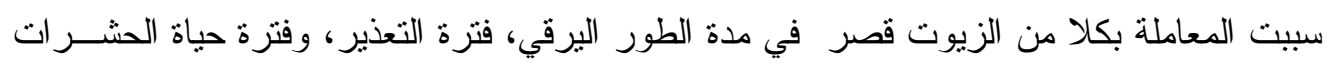

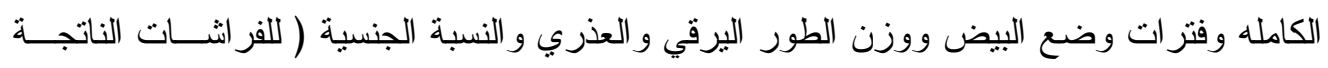

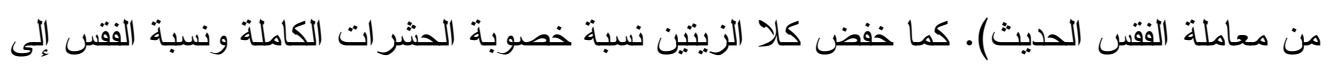

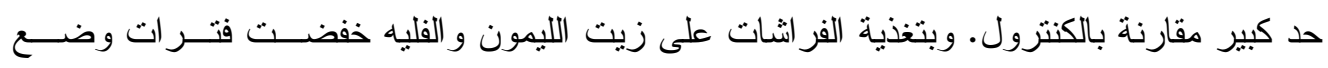

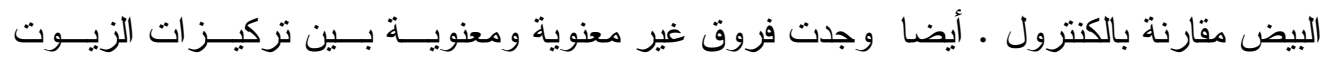

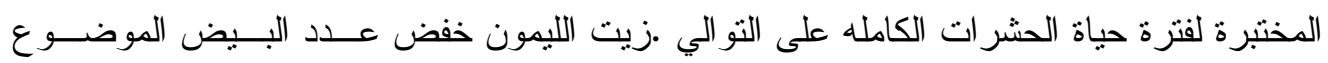

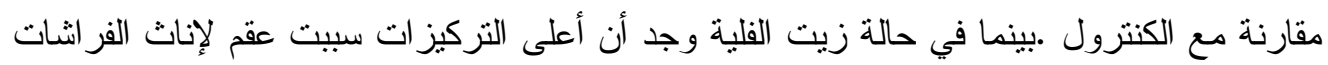

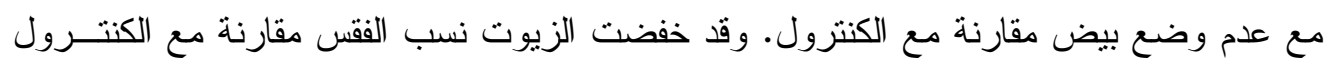

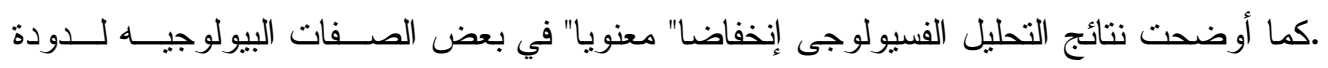

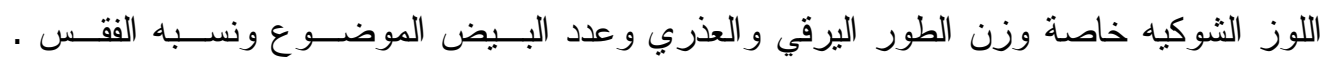

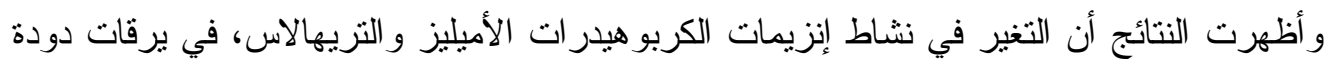

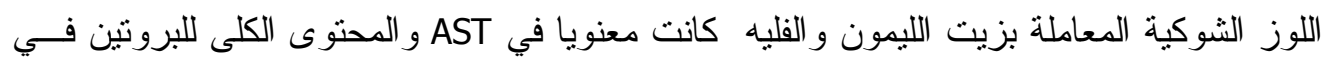

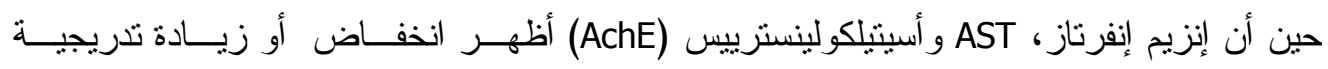

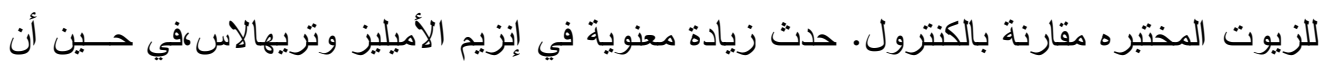

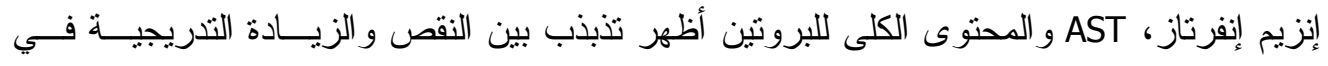

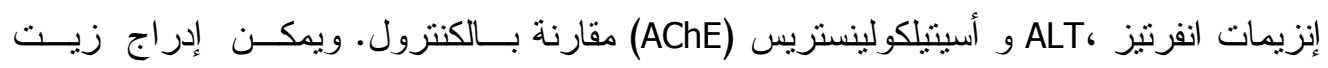

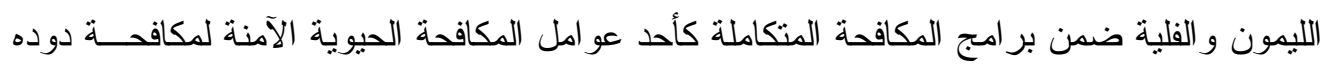

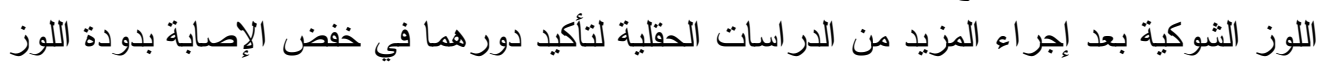

